\title{
The EU-Ukraine Association Agreement prior to the Vilnius Eastern Partnership Summit
}

\author{
Gunta Pastore \\ Department of Political Science, \\ Faculty of Social Sciences, \\ University of Latvia \\ Lomonosova Street $1 \mathrm{~A}$, \\ Riga LV-1019, Latvia \\ E-mail: gunta.pastore@gmail.com
}

Abstract: This paper seeks to explore how the EU policy on Ukraine evolved in the run-up to the Eastern Partnership Summit in Vilnius in November 2013. In particular, it looks into the preparations leading to the signature of the EU-Ukraine Association Agreement. Thereby it contributes to better understanding of the EU policy debate related to the associated negotiations with the Eastern Partnership countries.

Prior to the Vilnius Summit there were high expectations that signature of the EU-Ukraine Association Agreement would become a key deliverable of the summit. After the EU had postponed the signing of the agreement due to Ukraine's backsliding in democracy for several times, the process gained new momentum in 2013. It is suggested that exogenous factors, such as Russia's increasing pressure on Ukraine, contributed to consolidating the EU position.

However, at the last minute Ukraine suspended its signature of the agreement at the Vilnius Summit. While Ukraine's domestic developments and Yanukovych's deals with Russia can be blamed for this fiasco, the EU Member States take a large share of responsibility. Lack of creativity to find a way out of the deadlock, as well as lack of the political will on the part of EU leaders to fight for Ukraine explains why the Association Agreement turned out as a missed opportunity.

Keywords: Association Agreement, Eastern Partnership, EU, Russia, Ukraine 


\section{Introduction}

The Vilnius Eastern Partnership Summit in November 2013 failed to sign the long-awaited Association Agreement (AA) between Ukraine and the European Union (EU). Signature of the agreement was expected to be a highlight of the summit. Despite previous efforts, at the last minute, President Yanukovych returned to the dialogue with the Russian-led Customs Union. This was a heavy blow to the EU.

The Association Agreement has been negotiated already since 2007. However, under President Yanukovych the EU relations with Ukraine substantially deteriorated. Ukraine's domestic developments dominated by selective justice, imprisonment of the political opponents, as well as authoritarian ruling style. The EU responded by postponing the already finished AA. The EU's internal debate indicates that the lowest common denominator prevailed. The situation changed in 2013, when the EU consensus emerged. Why did the Member States, despite the ongoing lack of enthusiasm, finally came together in a unified fashion? It is suggested that the EU unity was facilitated by exogenous factors such as the increasing Russian pressure on Ukraine. In this sense, the EU approach towards Ukraine exhibited reaction to geostrategic factors. However, the Member States' divergent interests and overconfidence of the EU soft power could not compete with Russia's hard power. As a result, Yanukovych returned to Moscow.

\section{Prior to the Warsaw Eastern Partnership Summit}

Since Yanukovych became president in 2010, progress towards democratic consolidation stalled. Especially worrying developments took place in relation with the ex-Prime Minister Tymoshenko. After the elections, Yanukovych sought to neutralize his main opponent. Several criminal cases were brought against Tymoshenko. All in all, he openly ignored the EU democratic standards.

In this situation, the EU faced a substantial dilemma. On the one hand, the union could not compromise on its values. Ukraine was perceived as a frontrunner of the Eastern Partnership, and the first with whom the EU started talks on the AA. Now it was lagging behind Georgia and Moldova. Without Ukraine, the whole Eastern Partnership would be under threat. With the Eastern Partnership Summit in Warsaw in September 2011 approaching, the EU needed success. There was already trouble with another Eastern partner country-Belarus, who boycotted 
the Warsaw Summit due to the EU's frozen relations with Minsk. The EU was keen to ensure that Ukraine, the most prominent Eastern Partnership country, is on the right track.

However, the Warsaw Summit was overshadowed with fading prospects for democracy in Ukraine and the ongoing trial of Tymoshenko. Somewhat contrary, the summit declaration adopted a very positive language on Ukraine, praising productive negotiations on the Association Agreement and stressing that the summit looked forward to the possible finalization of negotiations by the end of 2011 (European Union, 2011). Also, European Commission's President Barroso was optimistic on Ukraine's chance to become the first Eastern Partnership country to finalize the AA. In fact, this unified position was not taken without intense internal debate. Beyond the unified EU's statements, the Member States advocated very divergent responses. Terms such as 'maybe', 'possible' signing of the AA till the end of 2011, appeared more often.

In the EU debate, a group of 'maximalists' - the Eastern European Member States, Poland, the Baltic countries, to some extent the Nordic countries and the UK - pushed for the EU's engagement in Ukraine. They argued that Ukraine is a key for Europe. Therefore the EU should not isolate it, allowing it to fall under Russia's influence. The EU should act strategically and engage in Ukraine despite Yanukovych's lack of reforms. Especially, the former Soviet countries among the EU Member States insisted on a tougher line towards Russia's influence in Ukraine. The most prominent role was adopted by Poland. Poland also seemed to be the main beneficiary of the AA, as its goods would be able to gain a strong market share in Ukraine.

On the other side in the EU debate were the 'minimalists'-Germany, France, Spain, and Italy. The southern countries were traditionally reluctant. The crucial aspect here is the fact that the relations between Ukraine and the most influential EU Member States - France and Germany - have always been attached to their relations with Russia (Youngs, 2011, p. 32). Germany has been desperate to avoid confrontation with Russia, its strategic partner (Barkin, 2014.) The same applies for France and the southern Member States. It cannot be ruled out that for some Member States the negative trends in Ukraine served as an excuse to delay signing the AA, which was strongly opposed by Russia. This way they could ease profitable bilateral deals with Russia. Reluctance of these states was reflected in the balanced EU policy vis-à-vis Ukraine. 


\section{Tymoshenko in prison: EU postpones the Association Agreement}

Despite the EU's strong warnings to Yanukovych at the Warsaw summit, Yanukovych ignored the EU values. Shortly after the Warsaw summit, in October 2011, Tymoshenko was sentenced for seven years in prison. The EU strongly condemned this Yanukovych's step. Although EU and Ukrainian experts had finished the technical preparations for signing the AA, Tymoshenko's imprisonment became its main obstacle. Even the most eager Ukraine's advocates in the EU remained without arguments. This switched the balance in the EU debate in favour to the minimalist group.

A majority of the Member States considered that the December 2011 EUUkraine Summit was not a proper timing to proceed with the AA. The agreement had to be ratified in all the 27 Member States. Several of them signalled a 'No' to ratification of the agreement in this situation. Germany indicated that it would not be possible to get parliamentary approval for the agreement if there are no changes in Ukraine. France said that the AA can be signed only if the Tymoshenko case is solved. Sweden said that without changes in Kyiv it would be a "suicide mission to try to get the Association Agreement signed through national parliaments" (KyivPost, 2012)

Subsequently, on the eve of the December 2011 EU-Ukraine Summit, the EU side made it clear that signing of the AA depended on Tymoshenko's fate. This came as major disappointment for Yanukovych. The December 2011 UkraineEU Summit stated that the ratification of the agreement depended on Ukraine's "respect for common values and the rule of law with an independent judiciary". Yanukovych expressed hope that the agreement would be signed soon.

The Association Agreement was initialled in March 2012, but only at the expert level. At the same time, there was growing pessimism on when it might be signed. In the EU circles, the dominating viewpoint was that the EU needs to wait until Ukraine's parliamentary elections in October 2012, which would be a litmus test for its respect of the common values. Regretfully, in this way the signing of the AA was postponed for one year. The overwhelming majority of the states supported a pause in relations with Yanukovych's regime. In the EU debate, critical voices dominated, despite a certain awareness that "swift signing of the AA would allow to avoid giving Putin the time and opportunity in which to exploit Ukraine's vulnerabilities to get Yanukovych to agree to join the Russian-led Customs Union, which would overturn the AA." (CEPS, 2012) 
In spring 2012, there was no substantial EU debate on Ukraine. The EU put further pressure on Yanukovych to provide free and fair elections. Some Member States were especially active. In March 2012, the Swedish, UK, Czech, Polish and German foreign ministers in their open letter stated that the October elections would be a "litmus test for democracy" and drew a symbolic parallel: "It is fair to say that the agreement has been imprisoned, and the Ukrainian leadership is holding the key" (The New York Times, 2012). Also, the May EU Foreign Affairs Council (FAC) reiterated the conditionality of the EU engagement, i.e. the October elections should be held according to international standards, addressing selective justice and reforms agreed in the Association Agenda.

In autumn 2012, the EU debate returned to the October elections. The EU institutions started to indicate that the AA could be signed till the end of 2012, depending on Ukraine's "homework", as said by Commissioner Füle. Also, Head of the EU Delegation to Ukraine Tombinski expressed hope that the technical approval of the AA would be completed before the end of 2012. He stressed that "very thorough technical work on this document is being carried out. [...] We hope to finish this work by the end of this year, possibly by the end of November" (KyivPost, 2013a).

\section{October 2012 elections: one more postponement of the agreement}

Ukraine's parliamentary elections on 28 October 2012 did not bring any positive results. International monitors, the Vienna-based OSCE, concluded that the elections were a step backwards. The EU High Representative Catherine Ashton agreed that the elections represented deterioration (EEAS, 2012).

The EU prepared to discuss what to do with the AA in the November FAC. Prior to the FAC meeting, Ukraine called the EU to unfreeze the EU-Ukraine agenda. Ukrainian Ambassador to the EU Yelisieiev believed that Ukraine has passed the test with the elections. He called to sign the AA in the coming EUUkraine Summit: "So let's continue with our EU agenda". Interestingly, without specifying Germany, he criticized that the largest EU country was the biggest obstacle. "Why is gas for certain EU countries much cheaper?" implying that Germany was rewarded by Russia for its tough line on Ukraine. (EurActiv, 2012)

In the EU circles, the new possible date for signing the AA started to circulatethe Vilnius Eastern Partnership Summit in November 2013. But then again it 
was one year ahead. Only the Ukrainian diplomats' and few Member States urged not to delay the AA. Importantly, also the policy experts called the EU to think creatively, not simply wait, but apply the AA, and put the pressure on Ukraine in other areas (Wilson, 2012). Yet, Commissioner Füle said that the AA would not be signed earlier than November 2013. For this Brussels expected Ukraine to address well-known EU concerns.

The November FAC debate revealed the same previous differences among the Member States. Only few countries were keen to consider the signing of the AA. The Eastern European Member States, such as the Czech Republic, Lithuania, Poland and Slovakia called for more strategic EU action. They argued that the AA should be signed not to push Ukraine into Belarus-type isolation (Rettman, 2012). Also, Latvian Foreign Minister Rinkēvičs called the EU not to reject Ukraine, but to proceed with signing of the AA (MFA Latvia, 2012). Contrary to this, Sweden, Finland, Denmark and the Netherlands believed the AA should be delayed until Yanukovych releases political opponents. The Nordic-Dutch group put forward strict criteria for the AA-freedom for Tymoshenko and reform of the judiciary. France and the UK were keeping a low profile, while Germany seemed to be undecided (Rettman, 2012).

It was at this stage that Germany adopted the crucial role. Seemingly, it did not happen without Poland's pressure. When Chancellor Merkel met Polish leader Tusk in November, she supported the Vilnius timetable. Another source said that Merkel - who promised to get Tymoshenko out of the prison — was less happy to take this step than her foreign minister Westerwelle. Hence, one may argue that the Germany's decisive step improved chances to gain the EU Member States' support for a new target date for the AA.

The 10 December FAC adopted the formal Council Conclusions on Ukraine. While the document declared that the October elections "constituted a deterioration", at the same time it offered a new target date. It stated that the EU is committed to sign the Association Agreement as soon as the Ukrainian authorities demonstrate determined action and tangible progress, possibly by the time of the Eastern Partnership Summit in Vilnius in November 2013 (European Union, 2012). The agreed text represented a compromise between the 'maximalist' and 'minimalist' groups. This provides the evidence of 'cooperative bargaining', where the 'minimalist' group agreed on the Vilnius timetable, whereas the 'maximalist' group — on the conditionality. As said, Germany's decision to support the Vilnius timetable was crucial here. For a long time Germany stayed neutral, but then suddenly joined the 'maximalist' group. Evidently, without its support a positive wording in the Conclusions 
on the Vilnius timetable would not be possible (Permanent Representation, 2013).

Hence, the 10 December FAC sent a signal to Ukraine on its readiness to restart relations. Yet, the EU leaders hesitated to invite Yanukovych to the EU-Ukraine Summit. A turning point seemed to be Yanukovych's decision to cancel, at the very last minute, his visit to Moscow (on 18 December), where he was due to talk with Putin about lowering of the gas prices and Ukraine's joining the Customs Union. In light of Yanukovych's demonstrated political choice, the EU leaders were ready to meet him at the highest level. The proposed date for the summit was 25 February 2013.

\section{The year 2013: new dynamics and the EU-Ukraine-Russia 'triangle'}

In 2013, in the words of Ukraine's Ambassador to the EU Yelisieiev (2013), "Ukraine entered the year which will decide the fate of the AA. This has been debated in kitchens and in the highest political offices". He also warned that "joining the Customs Union may grant Ukraine only short-term dividends in exchange for loss of sovereignty" (Yelisieiev, 2013).

While now the EU had given the green light for the AA and Yanukovych was welcomed in Brussels, he continued manoeuvring between the EU and Russia. His top priority was to get favourable gas price, and to secure the 2015 presidential elections. In turn, for Russia, maintaining influence over Ukraine was more than foreign policy priority, it was rather existential imperative (Paul, 2013). Putin himself made Ukraine his key target in relations with this 'near abroad'. Russia's Ambassador to the EU Chizhov wondered about Yanukovych's choice for the AA: "Did you see how you are treated in Europe? So let us agree with us again!"

In the EU, there was awareness on Ukraine's tough choice. In January 2013, EU politicians were trying to find a more flexible position toward Ukraine, realizing the risk of Ukraine turning toward Russia. However, while many EU politicians were concerned about Ukraine signing on with Russia, others believed that Ukraine was bluffing: "Kiev's interest in the Customs Union aims to raise concern in the west that it is 'losing' Ukraine to Russia" (Varfolomeyeva, 2013).

At the EU-Ukraine Summit on 25 February, Yanukovych declared that signing of the AA remains a priority for Ukraine. Both sides reaffirmed their commitment 
to signing the AA "as soon as tangible progress is demonstrated in the three areas," emphasized by the EU, possibly by the time of the Vilnius Summit. The leaders $[\ldots]$ looked forward to it achieving concrete progress by early May 2013” (European Union, 2013).

Thus, the spring of 2013 was crucial for the EU and Ukraine to proceed with the AA. The EU gave Yanukovych time until May to prove that his government is committed to political reform, as well as refuses the Customs Union. Head of the EU Delegation to Ukraine Tombinski explained that by May a certain progress with reforms should be shown as then the European Commission would hold a meeting during which it could formally approve the AA and ask the Member States and the European Parliament give it a mandate to sign the document at the Vilnius Summit.

Despite the re-established mutual confidence, Yanukovych almost immediately returned back to Kremlin. On 4 March, he was invited to Putin's residence outside Moscow. The main topic was the Customs Union. Putin promised, "if Ukraine joins the Customs Union, its GDP will increase between 1.5 and 6.5 per cent". Yanukovych resisted, offering instead to join the Customs Union as an observer.

Meanwhile, Ukraine's supporters in the EU, equipped with the Vilnius timetable, made efforts to achieve this goal. The already agreed EU language allowed them to use the 'rhetoric entrapment' within the EU debates. In parallel, they pressured Ukraine to meet the EU conditions to better persuade sceptical Member States. At this stage the efforts of the EU Member States focused on elite mediation. There were intensive bilateral and multi-lateral visit exchanges between Kyiv and the EU capitals, preparing a positive ground for signing the AA. In March, Polish ex-President Kwasniewski met Yanukovych, emphasizing that signing of the AA in Vilnius would be a breakthrough. Yanukovych assured that systemic reforms are being implemented in Ukraine. Afterwards, Polish and Hungarian presidents met Yanukovych, expressing their unconditional support to signing the AA in Vilnius. In June, German and the Baltic States' Foreign Ministers supported the AA with Ukraine.

However, the EU Member States remained divided. The Ukrainian media actively covered this, interpreting it as a "lack of consolidated position within the EU". Meanwhile, Russian pressure on Yanukovych increased. On 27 May, he urgently travelled to Sochi upon Putin's invitation. Russia had recently intensified its pressure with threats of trade restrictions if Ukraine signs the AA (Kiev Ukraine News Blog, 2013). Subsequently, on 31 May Ukraine signed 
the memorandum on the deepening cooperation with the Customs Union. Yanukovych's unexpected move increased worries in the EU on Ukraine's rapprochement with the Customs Union, despite its having a real chance to sign the AA.

In the midst of the brewing Russian-Ukrainian crisis, the maximalist Member States put more efforts into reaching the deal at the Vilnius Summit. Here, Germany played a crucial role, with its Foreign Minister Westerwelle, who intensified mediation efforts with Ukraine. Prior to the June FAC, he visited Kyiv, where he confirmed that Ukraine has taken steps towards meeting the EU criteria. In July, Westerwelle welcomed Ukraine's Foreign Minister Kozhara in Berlin. A month later, the Vice-Prime Minister Arbuzov visited Berlin. Arbuzov called for Germany's support, hoping it would say her "weighty word" in favour of the AA. Westerwelle assured that Germany had a strategic interest in Ukraine's EU development, and appreciated the efforts of the Ukrainian government to meet the required criteria (Federal Foreign Office, 2013). Thus, for the first time ever, the leading role among the Western countries supporting Ukraine's opposition belonged not to the US and Poland, but to Germany. Germany acted as the principal supporter of Ukraine's Association Agreement with the EU. These steps taken by Germany fit into the overall trend towards cooling the Russian-German relations (Voice of Russia, 2014).

At the FAC held at end of June, the EU ministers again discussed the issue of Ukraine. Overall, they reiterated the same messages - the need to speed up reforms to be able to sign the AA. This was "clearly at risk", according to Polish Foreign Minister Sikorski. He urged Ukrainian authorities to speed up with the EU's conditions by the end of summer, and not to wait until the last moment: "Everything is up to Ukraine". He promised that if Ukraine meets the conditions, Poland will do its best to persuade others to go ahead with the AA. Some Member States wanted to sign the AA, despite unresolved Tymoshenko's case. Support came from the European Parliament—President Schulz, who argued that "the EU should not discontinue the dialogue with Ukraine due to the case of former Premier Yulia Tymoshenko." (KyivPost, 2013b) 


\section{Russia's "trade war" and Yanukovych's U-turn}

It became more and more realistic that the AA could become the success story of the Vilnius Summit. Russia tightened the pressure. The more the Ukrainian leadership was inclined to the EU side, the more it angered Putin. On July $27-28$, Putin went to Ukraine to celebrate the $1025^{\text {th }}$ anniversary of the establishment of Kievan Rus'. However, there were no talks with Yanukovych. No statements followed about Ukraine joining the Customs Union. A day after his visit, Putin started a full-fledged trade war, blocking Ukrainian imports of chocolate and agricultural products. This was a heavy blow to Ukraine, especially as Yanukovych had left Ukrainian economy in a miserable state. Neither the International Monetary Fund nor the EU was prepared to help, given Yanukovych's poor economic and human rights policies (Åslund, 2013).

This was a clear sign to the EU on the seriousness of the situation. Commissioner Füle announced that any pressure on Ukraine related to signing the AA was unacceptable. On 12 September, the European Parliament issued a resolution on Russia's pressure on Eastern Partnership countries, including targeted sanctions against Ukraine's exports. The EP called on the Commission to take action in defence of the EU's partners (European Parliament, 2013). At the beginning of September, EU foreign ministers warned Russia not to press on neighbours, which tried to have tighter relations with the West.

Yanukovych made it clear that the country's course to European integration is beyond doubt. On September 5, Ukrainian lawmakers passed the first package of reforms demanded by the EU. On 18 September, Ukrainian government officially approved a draft of the AA, which the Prime Minister of Ukraine Azarov called a historic step $(R F E / R L, 2013)$. On this positive note, German Foreign Minister Westerwelle visited Kyiv, assuring Yanukovych that "the German Federal Government is working to eliminate the last barriers on the road to summit in Vilnius", while Yanukovych confirmed that Ukrainian parliament is conducting constructive work on the adoption of the necessary bills.

With Moscow's pressure increasing, while the EU demanded to release Tymoshenko, Yanukovych manoeuvered back and forth. Several developments started to indicate that he might have taken a U-turn. With a view to the 2015 presidential elections, which was a top priority for Yanukovych, he needed to stabilize the increasingly deteriorating economic situation. To solve this, it was important that Ukrainian goods have access to the Russian market (Konończuk, 2013). Shortly before the EU's expected bills were on the way to be passed 
in the Ukrainian Parliament, Yanukovych visited Putin. On 27 October they discussed 'urgent topics'. On 9 November Yanukovych again met Putin. He kept the content of the talks secret. After these meetings, the Ukrainian parliament, dominated by pro-Yanukovych deputies, suddenly postponed the voting. On 13 November, the parliament did not pass the bill on release of Tymoshenko for treatment abroad. The next session was on 19 November, a day after the FAC meeting which had to decide if the conditions were met for signing the AA.

In this situation, at the FAC on 18 November, the meeting of EU foreign ministers could not reach the final conclusion. They only repeated the conditions for signature of the AA- "determined action and tangible progress in three well-known areas". The HR Catherine Ashton stressed that the Tymoshenko case needed to be addressed. The UK asked more: "We want to see them fulfil the conditions set at the December 2012 FAC". In contrast, Lithuania, the EU Presidency, insisted that "Ukraine has already moved on very important segments [...], and the Commission has provided quite a positive assessment, so this is good news". German Foreign Minister Westerwelle warned that time was slowly running out: "Last-minute moves are not reasonable, they are extremely risky". As a result, the EU ministers agreed that "it is now up to Ukraine to act, they have to decide if they want to belong to Europe or to Russia".

After the FAC, the Member States put the last mediating efforts. Swedish and Polish foreign ministers travelled to Kyiv to review possible further developments. On 19 November, Polish Minister Sikorski assured that the EU did all they could to ensure the signing of the agreement. "The decision is now in the hands Yanukovych". He said that talks with the Ukrainian authorities were currently being conducted at all levels. Importantly, Sikorski indicated on Poland's more flexible approach-instead of discussions on the fulfilment of criteria for signing the AA he wanted to focus on how to help Ukraine resolve economic problems and implement the AA. (Ukrinform, 2013) On 19 November, Head of the EU delegation in Ukraine Tombinski stated that the EU is very positive about signing the Association Agreement in Vilnius. He assured that Brussels is doing everything possible to sign the agreement during the Vilnius Summit. On 20 November, Commissioner Füle said that he expects that the Ukrainian parliament would consider and adopt the remaining bills necessary for the signing of the AA.

These very last attempts were interrupted by Yanukovych's decision. On 21 November, the Ukrainian parliament rejected all six bills, refusing Tymoshenko to go abroad. The same day, the Ukrainian government announced the suspension of signing the AA in Vilnius. This decision had been taken for "reasons of 
national security", as well as the need to improve its declining trade with Russia. The government announced returning to the dialogue with the Customs Union.

The sudden switch by Yanukovych left EU policy towards Ukraine in tatters. On 22 November, HR Catherine Ashton expressed disappointment at Ukraine's decision. She saw this as a disappointment also for the people of Ukraine: "We believe that the future of Ukraine lies in a strong relationship with the EU and we stand firm in our commitment to the people of Ukraine" (EEAS, 2013).

In the light of these unexpected developments, Swedish Foreign Minister Bildt rightly asked whether this U-turn was "solely brutal Russian economic pressure, or reluctance by rent-seeking elites [...]. Ultimately it was a decision made by President Viktor Yanukovych, for which he carries full responsibility." (Financial Times, 2013)

\section{Conclusion}

To sum up, while President of Ukraine Yanukovych carries full responsibility for the fiasco of the long-awaited Association Agreement, the fault was also on the EU side. The opportunity to sign the AA was missed because most EU Member States were not nearly as interested in integrating Ukraine closer to the EU as Russia was interested to keep it in its sphere of influence. Also, the EU overestimated its attractiveness for Ukraine. Instead of finding creative ways on how to put pressure on Kyiv, the EU simply postponed the signing of the Association Agreement. This way, the EU with its conditionality indirectly pushed Ukraine back into Russia's sphere of influence.

Gunta Pastore is a Ph.D. student at the Department of Political Science of the University of Latvia. She holds a master's degree in Political Science and International Relations from the University of Latvia. She has also spent one year as a guest researcher at the Swedish National Defence College from 2012 until 2013. Gunta's research interests are related to the EU foreign policy making. In her thesis she explores how the Member States exert their influence on EU foreign policy making. 


\section{References}

Åslund, A. (2013), 'How Putin Lost Ukraine,' The Moscow Times, 21 August 2013. Retrieved from http://www.themoscowtimes.com/opinion/article/how-putin-lostukraine/484823.html [accessed Sep 2014]

Barkin, N. (2014), 'Russia ties compound German dilemma in Ukraine Crisis,' Reuters, 3 March 2014. Retrieved from http://www.reuters.com/article/2014/03/03/usukraine-crisis-germany-idUSBREA2215120140303

CEPS (2012), 'The Ukraine Question,' European Neighbourhood Watch, CEPS, no. 80 (March). Retrieved from http://www.ceps.eu/system/files/simplenews/2011/05/ NWatch80.pdf [accessed Sep 2014]

EEAS (2012), Joint statement by High Representative Catherine Ashton and Commissioner Štefan Füle on the parliamentary elections in Ukraine (28 October 2012), A 502/12, EEAS, 12 November 2012. Retrieved from http://www.consilium. europa.eu/uedocs/cms_Data/docs/pressdata/EN/foraff/133444.pdf [accessed Sep 2014]

(2013), Statement by EU High Representative Catherine Ashton on Ukraine, 131121/04, EEAS, 22 November 2013. Retrieved from http://eeas.europa.eu/ statements/docs/2013/131121_04_en.pdf [accessed Sep 2014]

EurActiv (2012), 'Ukraine seeks thaw in relations with the EU,' EurActiv, 19 November 2012. Retrieved from http://www.euractiv.com/europes-east/ukraine-wants-euagenda-unfrozen-news-516113 [accessed Sep 2014]

European Parliament (2013), European Parliament resolution on the pressure exerted by Russia on Eastern Partnership countries (in the context of the upcoming Eastern Partnership Summit in Vilnius), 2013/2826 (RSP), European Parliament, 12 September 2013

European Union (2011), Joint Declaration of the Eastern Partnership Summit, Warsaw, 14983/11 PRESSE 341, Council of the European Union, 29-30 September 2011. Retrieved from http://ec.europa.eu/europeaid/where/neighbourhood/eastern partnership/documents/warsaw_summit_declaration_en.pdf [accessed Sep 2014] (2012), 'EU Council Conclusions on Ukraine,' 3209 ${ }^{\text {th }}$ Foreign Affairs Council meeting, Council of the European Union, 10 December 2012. Retrieved from http:// www.consilium.europa.eu/uedocs/cms_Data/docs/pressdata/EN/foraff/134136. pdf [accessed Sept 2014]

(2013), 16 ${ }^{\text {th }}$ EU-Ukraine Summit: Joint Statement, 6811/13 PRESSE 72, Council of the European Union, 25 February 2013. Retrieved from https://www.consilium. europa.eu/uedocs/cms_Data/docs/pressdata/EN/foraff/135667.pdf [accessed Sep 2014] 
Federal Foreign Office (2013), 'Foreign Minister Westerwelle Meets First Vice Prime Minister of Ukraine,' Federal Foreign Office Press Release, 30 July 2013.

Financial Times (2013), 'Ukraine has postponed an opportunity to prosper,' Debattartikel, 22 November 2013. Retrieved from http://www.regeringen.se/sb/d/7416/a/229097 [accessed Sep 2014]

Kiev Ukraine News Blog (2013), 'Yanukovych meets Putin to discuss trade,' 27 May 2013. Retrieved from http://news.kievukraine.info/2013/05/sochi-russiapresident-viktor.html [accessed Sep 2014]

Konończuk, W. (2013), 'Ukraine withdraws from signing the Association Agreement', OSW, 27 November 2013. Retrieved from http://www.osw.waw.pl/en/publikacje/ analyses/2013-11-27/ukraine-withdraws-signing-association-agreement-vilniusmotives-and [accessed Sep 2014]

KyivPost (2012), 'Fule: EU-Ukraine Association Agreement to be initialed within a month,' 28 February 2012. Retrieved from http://www.kyivpost.com/ content/ukraine/fule-eu-ukraine-association-agreement-to-be-initia-123265. html?flavour=mobile [accessed Sep 2014]

(2013a), EU hopes for technical approval of the Association Agreement by the end of year,' 16 October 2013. Retrieved from http://www.kyivpost.com/content/ ukraine/brussels-hopes-for-technical-approval-of-ukraine-eu-associationagreement-by-end-of-year-314457.html [accessed Sep 2014]

_ (2013b), 'The EU should continue dialogue with Ukraine,' 28 June 2013. Retrieved from http://www.kyivpost.com/content/ukraine/ep-president-eu-should-continuedialog-with-ukraine-despite-tymoshenkos-case-326271.html?flavour=mobile [accessed Sep 2014]

MFA Latvia (2012), 'Foreign Minister Rinkēvičs: Latvia stands for further EU-Ukraine Cooperation,' Press Release, Ministry of Foreign Affairs Latvia, 21 November 2012. Retrieved from http://www.mfa.gov.lv/en/news/press-releases/2012/ november/21-1/ [accessed Sep 2014]

Paul, A. (2013), 'Russia cranks up pressure on Ukraine,' EUobserver, 6 September 2013. Retrieved from http://blogs.euobserver.com/paul/2013/09/02/russia-cranksup-pressure-on-ukraine/ [accessed Sep 2014]

Permanent Representative (2013), Interview with Permanent Representative in Brussels, 18 January, 2013.

Rettman, A. (2012), "EU-Ukraine Summit 'unlikely' this year," EUobserver, 5 November 2012. Retrieved from http://euobserver.com/foreign/118094 [accessed Sep 2014]

RFE/RL (2013), "Ukraine's Cabinet backs the EU Association Agreement," Radio Free Europe/Radio Liberty, 18 November 2013. Retrieved from http://www. rferl.org/content/ukraine-eu-membership-association-agreement-governmentapprove/25109791.html [accessed Sep 2014] 
The New York Times (2012), 'Ukraine's slide,' 4 March 2012. Retrieved from http:// www.nytimes.com/2012/03/05/opinion/05iht-edbildt05.html [accessed Sep 2014] Ukrinform (2013), 'Poland did all to ensure signing of the Association,' 19 November 2013. Retrieved from http://www.ukrinform.ua/eng/news/poland_did_all_to_ ensure_signing_of_eu_ukraine_association_agreement__sikorski_313077 [accessed Sep 2014]

Varfolomeyeva, A. (2013), 'Ukraine will sign agreement with EU,' EPOCH, 16 January 2013. Retrieved from http://www.theepochtimes.com/n2/world/ukraine-will-signagreement-with-eu-336429.html [accessed Sep 2014]

Voice of Russia (2014), 'US taking advantage of Ukraine crisis to upset RussiaGermany relations,' 21 February 2014. Retrieved from http://voiceofrussia. com/news/2014_02_21/US-taking-advantage-of-Ukraine-crisis-to-upset-RussiaGermany-relations-6124/ [accessed Sep 2014]

Wilson, A. (2012), The EU and Ukraine after the 2012 Elections, ECFR EU Policy Memo, ECFR/65, European Council for Foreign Relations.

Yelisieiev, A. (2013), 'Seven Myths on EU-Ukraine Association Agreement,' Mission of Ukraine to the EU, 7 January 2013. Retrieved from http://ukraine-eu.mfa. gov.ua/en/press-center/news/9473-7-mifiv-shhodo-ugodi-pro-asociaciju-mizhukrajinoju-ta-jes [accessed Sep 2014]

Youngs, R. (2011), "EU Policy on Ukraine during and since the Orange Revolution: 'A door neither closed nor open'," in D. Thomas (ed.) Making EU Foreign Policy: National Preferences, European Norms and Common Policies, Basingstoke: Palgrave Macmillan. 